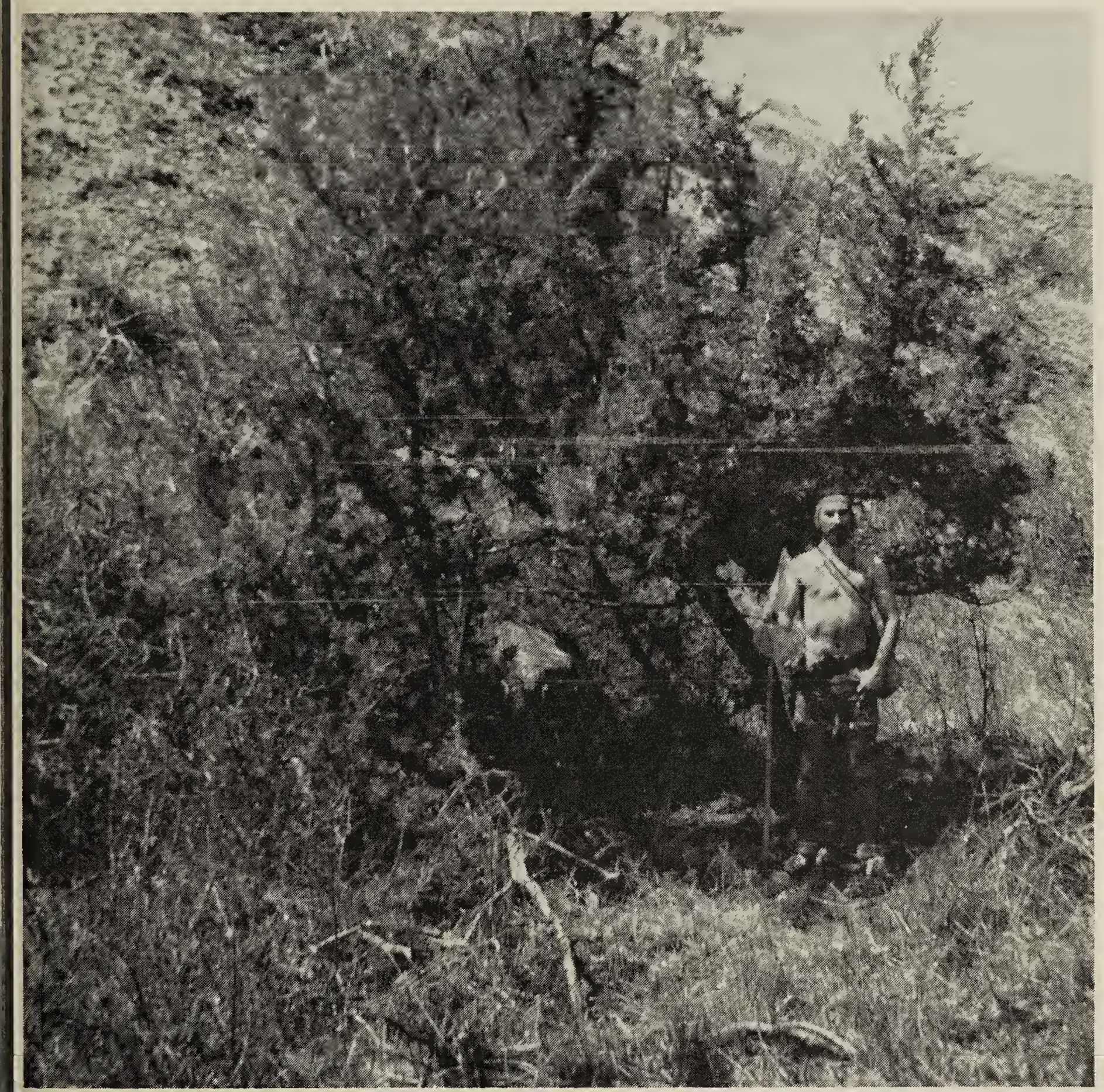

\title{
EXTRA-LIMITAL OCCURRENCE OF ROCKY MOUNTAIN JUNIPER IN SOUTHEASTERN ALBERTA
}

W. W. SMITH and C. A. WALLIS, 8220 Elbow Drive, Calgary, Alberta

Rocky Mountain Juniper (Juniperus scopulorum Sarg.) is an erect shrub, or small tree, which is distributed primarily west of the Rocky Mountain Divide. However, there are numerous records of this species east of the continental divide; most from the United States. Little lists 15 locations in the eastern half of Montana and 11 locations in North Dakota. ${ }^{3}$
In Alberta, this juniper occurs with some regularity at three locations east of the continental divide, but still within the mountainous regions at Banff, Crownest Pass and Waterton Lakes. Kuijt and Trofymow list two extra-limital occurrences in Alberta." These locations are Glenwood (near Cardston) and just north of Lethbridge. Kuijt and Trofymow stated 